Online: http://journal.uny.ac.id/index.php/jppfa

\title{
PENDIDIKAN KESETARAAN DI RUMAH INKLUSIF DESA KEMBARAN KECAMATAN DAN KABUPATEN KEBUMEN
}

\author{
Mustolih \\ MA Salafiyah Wonoyoso Kebumen \\ Jl. Walikonang 3 Wonoyoso, Gunungmujil, Bumirejo, Kebumen, Jawa Tengah 54316, Indonesia \\ Email: mustolihbrs@gmail.com,
}

\begin{abstract}
Abstrak
Penelitian ini bertujuan untuk menganalisis pola pendidikan di Rumah Inklusif Kembaran, dasar untuk pendidikan inklusif di sana dan tantangan dalam mengimplementasikan pendidikan inklusif di sana. Segmentasi lembaga pendidikan berdasarkan perbedaan agama, etnis, dan bahkan perbedaan kemampuan baik secara fisik maupun mental yang dimiliki oleh siswa masih terjadi di Indonesia, ini menunjukkan bahwa pendidikan di Indonesia belum mengakomodasi keragaman. Temuan pendidikan yang dilakukan di Rumah Inklusif adalah pendidikan pembebasan yang menempatkan anak-anak luar biasa atau anak-anak dengan kebutuhan khusus untuk belajar bersama dengan anak-anak normal dalam satu kelas di rumah joglo dekat dengan tempat mereka tinggal. Yang dimaksud dengan pembebasan adalah bahwa siswa diberi kebebasan untuk menentukan menu pendidikan mereka sendiri. Tantangan penerapan pendidikan inklusif di rumah inklusif Kembaran Kebumen adalah kurangnya pemahaman publik tentang kondisi anak-anak penyandang cacat. Dalam proses pendidikan, rumah inklusif terbatas dalam hal fasilitas, dan ada kekurangan staf sukarela untuk membantu anak-anak cacat. Hal ni terbukti dengan banyaknya fasilitas publik, terutama di Kebumen, yang tidak ramah bagi penyandang cacat. Kelahiran rumah inklusif di Kebumen adalah bentuk perlawanan terhadap kurangnya perhatian pemerintah dalam menangani anak-anak berkebutuhan khusus di Kebumen. Pemerintah belum melakukan apa-apa, tepatnya untuk mengecualikan anak-anak penyandang cacat di sekolah-sekolah Luar Biasa (SLB). Ini membuat siswa apalagi orang tua merasa minder.
\end{abstract}

Kata kunci : inklusif, difabel, persamaan

\section{EQUALITY PEDAGOGY DI RUMAH INKLUSIF DESA KEMBARAN KECAMATAN DAN KABUPATEN KEBUMEN}

\begin{abstract}
This study aims to analyze the pattern of education in the Kembaran Inclusive Houses, the basis for inclusive education there and the challenges of implementing inclusive education there. Segmentation of educational institutions based on differences in religion, ethnicity, and even differences in abilities both physically and mentally possessed by students still occur in Indonesia, this indicates that education in Indonesia has not accommodated diversity. Findings of inclusive education carried out in Inclusive Houses is a liberation education that places exceptional children or children with special needs to study together with normal children in one class at a joglo house close to where they live. What is meant by liberation is that students are given the freedom to determine their own education menu. The challenge of implementing inclusive education in Kembaran Kebumen inclusive homes is the lack of public understanding the conditions of children with disabilities. In the process education, inclusive homes are limited in terms of facilities, and there is a lack of volunteer staff to assist disabled children. This hall is proven by the many public facilities, especially in Kebumen, which are not friendly to the disabled. The birth of an inclusive house in Kebumen is a form of resistance to the lack of government attention in dealing with children with special needs in Kebumen. The government has not done anything, precisely to exclude children with disabilities in Extraordinary schools. This makes students more than parents feel less.
\end{abstract}

Keywords: inclusive, difabel, equality 


\section{PENDAHULUAN}

Segmentasi lembaga pendidikan yang berdasar perbedaan agama, etnis, dan bahkan perbedaan kemampuan baik fisik maupun mental yang dimiliki oleh siswa masih terjadi di Indonesia hal ini mengindikasi pendidikan di Indonesia belum mengakomodasi keberagaman. Segmentasi lembaga pendidikan ini telah menghambat para siswa untuk dapat belajar menghormati realitas perbedaan dan keberagaman dalam masyarakat (Wahab, 2011, p. 11).

Dilematis, di saat Negara wajib memberikan pelayanan pendidikan bermutu kepada setiap warganya tanpa terkecuali termasuk mereka yang memiliki perbedaan dalam kemampuan (difabel) seperti yang tertuang pada UUD 1945 pasal 31 ayat 1 . sementara pendidikan adalah kebutuhan dasar setiap manusia sehingga anak-anak yang memiliki perbedaan kemampuan (difabel) disediakan fasilitas pendidikan khusus disesuaikan dengan derajat dan jenis difabelnya yang disebut dengan Sekolah Luar Biasa (SLB). Secara modernis dari prinsip efisiensi ini sudah selesai tetapi dari prinsip efektifitas hal itu belum terukur. Satu-satunya keuntungan dalam sistem pendidikan SLB adalah lokalisasi, para penyandang Diva ini telah ditempatkan dalam satu wadah, tetapi sebenarnya negara telah membangun tembok eksklusifisme bagi anak-anak yang berkebutuhan khusus ini. Tembok eksklusifisme tersebut dalam tahap sosialisasi manusia tanpa disadari telah menghambat proses saling mengenal antara anak-anak difabel dengan anak-anak non-difabel .

Akibat sistem pendidikan tersebut dalam interaksi sosial di masyarakat kelompok difabel menjadi komunitas yang teralienasi dari dinamika sosial di masyarakat. Masyarakat menjadi tidak akrab dengan kehidupan kelompok difabel. Sementara kelompok difabel sendiri merasa keberadaannya bukan menjadi bagian yang integral dari kehidupan masyarakat di sekitarnya. Untuk mengatasi masalah tersebut pendidikan inklusif diharapkan dapat memecahkan salah satu persoalan dalam penanganan pendidikan bagi anak berkebutuhan khusus selama ini.

Salah satu komunitas yang prihatin dengan eksklusifisme para difabel adalah Rumah Inklusif. Beralamat di Desa Kembaran Kecamatan Kebumen. Rumah yang dipimpin oleh
Muinatul Khoeriyah (Mbak Iin) sekaligus pendiri Rumah Inklusif itu mewadahi dan menampung semua komunitas keluarga Difabel. Mayoritas keluarga yang masuk dan menjadi anggota dari rumah inklusif itu adalah keluarga yang salah satu anggota kelarganya mengalami disabilitas atau difabel. Meksipun begitu Mbak Iin berhasil mengelola para keluarga Diva itu dalam sebuah desain rumah inklusif. Bentuk rumah itu sederhana berbentuk Joglo atau rumah jawa menjadi pilihan pendiri Mbak Iin bersama suaminya Ahmad Murtajib, "Untuk nguri-uri budaya" Tutur Mbak Iin saat ditanya.

Di rumah sederhana itu terrangkum berbagai cerita baik suka, duka maupun pilu para orang tua yang memiliki anak berkebutuhan khusus. Saat di tempat-tempat lain anakanak mereka ditolak sekolah di sinilah mereka diterima dan menjadi bagian dari kehidupan mereka. (Iin, Wawancara, 23/11/2018) Mereka diperbolehkan memilih sendiri aktifitas yang disenangi, dan sedapat mungkin rumah inklusif memfasilitasinya. Di sinilah terpenuhi kebutuhan akan aktualisasi diri mereka, salah satu hierarkhi kebutuhan menurut humanisme (Gobel, 1987).

Berbagai kegiatan untuk mengaktifkan sikap inklusif digelar di rumah ini. Satusatunya yang dilarang di rumah ini adalah eksklusifisme. Kegiatan penting di dalam rumah inklusif itu ada dua yang menonjol. Pertama pembuatan batik Pegon yang sudah dua kali dilounching. Dan pembelajaran musik angklung atau musik kolaborasi dari alat-alat petik dan angklung. Musik ini diberi nama jaelangkung. Pelatihan musik kolaboratif ini dipimpin oleh langsung oleh Agus Mursalin dan dibina oleh Pujiono pembina rumah inklusif. Pujiono sehari-hari bekerja di Kementerian Agama menjadi penyuluh di Kementerian Agama Kabupaten Kebumen (Iin, Wawancara, 23/11/2018).

Pada saat acara launching Batik Pegon dihadiri oleh beberapa komponen masyarakat di antaranya adalah pendeta Teguh dari Gereja GKI Kebumen sendiri, Ahmad Murtajih Direktur setara Syarikat direktur Serikat, Mustolih News dari Kebumen dan Beberapa elemen lain seperti Mas Taufik Hidayat dosen di UNU Surakarta, Irma Susanti. Acara itu didesain dengan sangat unik. Diawali dengan diskusi penggalian terhadap nilai-nilai yang terkandung di dalam batik Pegon yang selama ini tak terungkap. Dari diskusi itu di awal pertemuan 
itu terungkap bahwa batik Pegon itu adalah sandi atau alat perjuangan. Tentang batik pegon ini ternyata memiliki sejarah yang panjang. Diawali saat terjadi penjajahan di Indonesia para ulama Nusantara menjadikan Pegon ini sebagai alat komunikasi berbasis sandi yang rahasia yang tidak diketahui oleh Belanda. Jadi surat-menyurat itu dilakukan dalam rangka berkomunikasi antar ulama dan pejuang tanpa diketahui oleh orang lain terutama penjajah Belanda. Dalam konteks sekarang mampukah pegon itu juga bisa menjadi alat perjuangan. Dalam konteks ini batik Pegon adalah alat perjuangan dari para difabel di dalam rumah inklusif ini untuk berjuang memperoleh hak-haknya sebagai difabel salah satunya kemudian dipakai juga untuk antisipasi atau melawan hoax.

Batik Pegon di rumah ini memiliki beberapa tema yang menarik. Di antaranya adalah ngupati, Jaa zaidun, Guyub Rukun dan lain-lain. Uniknya setiap tema setiap edisi seri itu mempunyai sejarah epistemologi yang kuat seperti contoh ngupati itu lahir dari tradisi di Jawa ngupati artinya pada saat anak berada di dalam kandungan 4 bulan di lakukanlah selamatan. Pada saat 4 bulan janin di kandungan menurut keyakinan mereka itu ditiuplah roh ke janin yang ada. Saat dalam kandungan inilah anak difabel ini orang tuanya diperingati peristiwa 4 bulan atau ngupati. Ini menjadi peristiwa yang sangat sakral, ada penyesalan di situ, muncul tanya apa adakah yang salah dalam proses peristiwa ngupati itu.

Dalam pengamatan awal, di rumah inkulusif itu terjadi proses penanaman sikapsikap inklusif sebagai bentuk pendidikan terbuka, proses menuju multukultural tercipta secara langsung dan tanpa sadar, di bawah persamaan rasa dan aktualisasi diri.

Masalah utama dalam tulisan ini adalah bagaimana pola pendidikan di Rumah Inklusif Kembaran, landasan pendidikan inklusif di Rumah inklusif Kembaran Kebumen, dan tantangan implementasi pendidikan inklusif di Rumah Inklusif Kembaran Kebumen.

\section{METODE PENELITIAN}

Penelitian ini berusaha mengetahui dan mendeskripsikan dengan jelas tentang strategi pembelajaran equality pedagogy di rumah Inklusif Inklusif Desa Kembaran Kab. Kebumen.

Penelitian ini termasuk kategori penelitian lapangan (field research). Ditinjau dari segi sifat-sifat data maka termasuk dalam penelitian kualitatif. Jika di tinjau dari sudut kemampuan atau kemungkinan penelitian dapat memberikan informasi atau penjelasan, maka penelitian ini termasuk penelitian termasuk penelitian deskriptif.

Data digali melalui wawancara mendalam (indeept interview) dan observasi lapangan. Teknik yang digunakan dalam wawancara adalah wawancara tidak terstruktur (unstandarized interview) yang dilakukan tanpa menyusun suatu daftar pertanyaan yang ketat. Selanjutnya wawancara unstandarized ini dikembangkan menjadi tiga teknik, yaitu: (1) Wawancara tidak terstruktur (unstructured interview atau passive interview), dengan wawancara ini bisa diperoleh data "emic (Nasution, 1988, p. 71) (2) Wawancara agak terstruktur (some what structured interview or active interview), dengan wawancara ini dapat diperoleh data "etic"; 3) wawancara sambil lalu (casual interview).

Teknik analisis data dilakukan dengan mengorganisasikan data, memilah-milahnya menjadi satuan yang dapat dikelola, mensintesiskannya, mencari dan menemukan apa yang penting dan apa yang dipelajari dan memutuskan apa yang dapat diceritakan kepada orang lain (Moleong, 2001, p. 248). Pada tahap ini data dikerjakan dan dimanfaatkan sedemikian rupa sampai berhasil menyimpulkan kebenaran-kebenaran yang dapat dipakai untuk menjawab pertanyaan atau persoalan-persoalan yang diajukan dalam penelitian. Adapun metode yang digunakan untuk mengelola data kualitatif adalah dengan menggunakan metode induktif.

\section{HASIL PENELITIAN DAN PEMBAHASAN}

Inklusi berasal dari bahasa Inggris "inclusion" berarti penerimaan anak-anak yang memiliki hambatan ke dalam lingkungan, kurikulum, interaksi sosial dan konsep diri atau visi misi sekolah. Inklusif juga dapat diartikan sebagai cara berfikir dan bertindak yang memungkinkan setiap individu merasa diterima dan dihargai (Smith, 2012, p. 45). Lebih jauh lagi inklusif berarti semua anak dapat diterima meskipun konsep "semua anak" harus cukup jelas, dan masih sulit bagi banyak orang untuk memahaminya (Sapon-Shevin, 2007, p. 10).

Ahli pendidikan mengemukakan konsep pendidikan inklusif secara beragam, meski 
punya tujuan sama. Ahli pendidikan mendefinisikan pendidikan inklusif. Stainback menyatakan bahwa sekolah inklusif adalah sekolah yang menampung semua siswa di kelas yang sama, berbeda dengan Staub dan Peck yang mengemukakan pendidikan inklusif adalah penempatan anak berkelainan ringan, sedang, dan berat secara penuh di kelas. Hal ini menunjukkan kelas reguler merupakan tempat belajar yang relevan bagi anak-anak berkelainan, apapun kelainan jenisnya (Tarmansyah, 2009, p. 76).

Pernyataan yang paling berbeda adalah Sirinam Khalsa menyatakan bahwa pendidikaninklusif adalah suatu cara untuk menghilangkan model segregasi atau pemisahan anakanak berkelainan yang belajar dengan cara yang berbeda (Khalsa, 2004, p. 2). Sirinam Khalsa membuat kelas tidak boleh dipisah antara penyandang disabilitas dengan siswa lainnya. Didukung oleh Sapon-Shevin yang mendefinisikan pendidikan inklusif sebagai sistem layanan pendidikan yang mempersyaratkan agar semua anak berkelainan dilayani di sekolah-sekolah terdekat di kelas reguler bersama-sama teman seusianya.

Menguatkan pernyataan Khalsa dan Sapon-Shevin, Depdiknas menegaskan bahwa pendidikan inklusif didefinisikan sebagai Sistem layanan pendidikan yang mengikutsertakan anak berkebutuhan khusus belajar bersama dengan anak sebayanya di sekolah reguler yang terdekat dengan tempat tinggalnya. Dengan demikian penyelenggaraan pendidikan inklusif menuntut pihak sekolah untuk melakukan penyesuaian baik dari segi kurikulum, sarana prasarana pendidikan, maupun sistem pembelajaran yang disesuaikan dengan kebutuhan dan karakteristik peserta didik (siswa).

Peraturan Menteri Pendidikan Nasional RI Nomor 70 tahun 2009 (Menteri Pendidikan Nasional Republik Indonesia, 2009), menyebutkan pendidikan inklusif adalah sistem penyelenggaraan pendidikan yang memberikan kesempatan kepada semua peserta didik yang memiliki kelainan dan memiliki potensi kecerdasan dan/atau bakat istimewa untuk mengikuti pendidikan atau pembelajaran dalam satu lingkungan pendidikan secara bersama-sama dengan peserta didik umumnya (Geniofam, 2010, p. 61).

Pendidikan inklusif berarti sekolah harus mengakomodasi semua anak tanpa memandang kondisi fisik, intelektual, sosial, emosio- nal, linguistik atau kondisi lainnya. Ini harus mencakup anak-anak penyandang cacat dan berbakat. Anak-anak jalanan dan pekerja, anak berasal dari populasi terpencil atau yang berpindah-pindah. Anak dari kelompok etnis minoritas, linguistik atau budaya dan anak-anak dari area atau kelompok yang kurang beruntung atau termajinalisasi.

Inti pendidikan inklusif adalah hak azazi manusia atas pendidikan. Seperti informasi pada Deklarasi Hak Azazi Manusia tahun 1994, yang intinya adalah hak agar tidak didiskriminasi. Konsekuensi logis dari hak ini adalah bahwa semua anak punya hak menerima pendidikan. Diskriminasi atas dasar kecacatan, etnis, agama, bahasa, jenis kelamin, kemampuan dan lain-lain adalah bentuk pelanggaran serius.

Jadi secara spekulatif dapat disimpulkan pendidikan inklusif adalah pendidikan yang menempatkan anak luar biasa atau anak berkebutuhan khusus belajar bersama dengan anak normal dalam satu kelas di sekolah umum yang dekat dengan tempat tinggalnya.

Permendiknas Nomor 70 Tahun 2009

Pasal 2 mengatur bahwa setiap peserta didik yang memiliki kelainan fisik, emosional, mental dan sosial atau memiliki kecerdasan dan/ atau bakat istimewa berhak mengikuti pendidikan secara inklusif pada satuan pendidikan tertentu sesuai kebutuhan dan kemampuannya. Pada pasal 3 juga disebutkan bahwa peserta didik yang memiliki kelainan sebagaimana dimaksud terdiri atas tunanetra, tunarungu, tunawicara, tunagrahita, tunadaksa, tunalaras, berkesulitan belajar, lamban belajar, autis, memiliki gangguan motorik, menjadi korban penyalahgunaan narkoba, obat terlarang dan zat adiktif lainnya, memiliki kelainan lainnya, tunaganda (Menteri Pendidikan Nasional Republik Indonesia, 2009).

Anak berkebutuhan khusus adalah anak yang memiliki perbedaan sedemikian rupa dari anak rata-rata dari segi fisik, mental, emosi, sosial, atau gabungan dari ciri-ciri itu dan menyebabkan mereka mengalami hambatan untuk mencapai perkembangan yang optimal dan oleh karenanya mereka memerlukan layanan pendidikan khusus (Iswari, 2008, p. 40).

Istilah lain bagi anak berkebutuhan khusus adalah anak luar biasa, anak cacat dan juga anak cerdas istimewa dan bakat istimewa (Ilahi, 2013, pp. 51-52; Mudjito, Harizal, \& 
Elfindri, 2012, p. 25). Termasuk anak dengan kebutuhan khusus adalah anak tunanetra, yaitu anak yang mengalami kelainan kehilangan ketajaman penglihatan sedemikian rupa sehingga penglihatannya tidak dapat digunakan untuk melakukan aktivitas sehari-hari termasuk untuk sekolah sehingga memerlukan layanan pendidikan khusus.

Anak tunarungu, yaitu anak yang mengalami kehilangan kemampuan mendengar, baik kehilangan kemampuan mendengar sama sekali maupun kehilangan kemampuan mendengar sebagian. Anak tunagrahita, yaitu anak yang memiliki keterbatasan perkembangan fungsi-fungsi inteligensi, kapasitas inteligensinya berada di bawah rata-rata anak. Anak tunadaksa, yaitu anak yang memiliki kelainan fungsi fisik yang sedemikian rupa sehingga mengganggu proses pembelajaran yang biasa digunakan bagi siswa umum.

Anak tunalaras, yaitu anak dengan gangguan emosional, anak dengan kekacauan psikologis, atau anak dengan hambatan mental. Anak berkesulitan belajar, adalah anak yang mengalami kesulitan atau gangguan dalam belajar bidang akademik dasar sebagai akibat terganggunya sistem saraf yang terkait atau pengaruh secara langsung dari berbagai faktor lainnya dan ditandai dengan kesenjangan antara potensi yang dimiliki dengan prestasi yang dicapai. Anak lambat belajar, yaitu siswa yang inteligensinya berada pada taraf perbatasan dengan IQ 70-85 berdasarkan tes inteligensi baku. Anak berbakat, yaitu anak yang secara umu keberbakatannya ditandai dengan ciri IQ yang secara signifikan di atas rata-rata anak biasa dan mempunyai karakteristik tertentu (Iswari, 2008, pp. 45-76).

Anak autisme, yaitu anak yang sangat asyik dengan dirinya sendiri seolah-olah ia hidup dalam dunianya sendiri. Autisme merupakan suatu keadaan ketidakmampuan seseorang melakukan kontak sosial dengan lingkungannya dengan berbagai komunikasi.

Prinsip pendidikan inklusif adalah jaminan akses dan peluang sama bagi anak Indonesia untuk memperoleh pendidikan tanpa memandang latar belakang kehidupan mereka. Beberapa prinsip dasar pendidikan inklusif di antaranya. Pendidikan inklusif membuka kesempatan untuk semua jenis siswa. Pendidikan inklusif merepresentasi pihak termarginal dan terbelakang dari lingkungannya. Representasi pendidikan inklusif bukan saja menolak diskri- minasi dan ketidakadilan, melainkan perjuangan hak azazi manusia yang terbelenggu hegemoni penguasa. Pendidikan inklusif tidak saja menjadi konsep pendidikan yang menekankan pada kesetaraan, tetapi juga memberikan perhatian penuh pada semua kalangan anak yang mengalami keterbatasan fisik maupun mental. Pendidikan inklusif mengusung tema besar tentang pentingnya menghargai perbedaan dalam keberagaman (Ilahi, 2013, pp. 51-52).

Prinsip dasar pendidikan inklusif menghindari aspek negati labeling. Prinsip dasar ini menjadi karakter pendidikan inklusif. Ketika muncul pelabelan kepada anak berkebutuhan khusus, di situlah muncul stigma negatif yang menyudutkan anak dengan keterbatasan dan kekurangannya. Pelabelan selain sangat berbahaya dan bisa menimbulkan kecurigaan, tetapi juga dapat mencipta ketidakadilan menghargai perbedaan antara sesama. Salah satu dampak buruk dar labelin adalah munculnya inferioritas bagi pihak yang diberi label negatif.

Pendidikan inklusif selalu melakukan Check dan Balances. Salah satu keuntungan dari kehadiran pendidikan inklusif adalah selalu melakukan check dan balances. Kehadiran pendidikan inklusif bukan sekedar konsep percobaan yang hanya muncul dalam wacana belaka, melainkan bisa menjadi konsep ideal yang berperan penting dalam penyelenggaraan pendidikan berbasis check dan balances. Sangat antusias menyambut kehadiran pendidikan inklusif karena disamping menciptakan alternatif baru juga menghadirkan satu gagasan praktis yang dapat dilaksanakan tanpa harus mengalami kesulitan berarti dalam konteks pelaksanaannya.

Prinsip pembelajaran yang harus menjadi perhatian guru di sekolah inklusi dijelaskan Idiyanto sebagai prinsip motivasi. Guru harus terbiasa memotivasi siswa agar tetap bergairah dan bersemangat mengikuti kegiatan pembelajaran (Indianto, 2013, pp. 21-22).

Prinsip latar/konteks. Guru perlu mengenal siswa secara mendalam, menggunakan contoh, memanfaatkan sumber belajar yang ada di lingkungan sekitar, dan semaksimal mungkin menghindari pengulangan-pengulangan materi pengajaran yang sebenarnya tidak terlalu perlu bagi anak.

Setiap anak melakukan kegiatan pembelajaran, guru harus merumuskan tujuan secara jelas, menyiapkan bahan dan alat yang 
sesuai serta mengembangkan strategi pembelajaran yang tepat. Prinsip hubungan sosial dalam kegiatan belajar mengajar, guru perlu mengembangkan strategi pembelajaran yang mampu mengoptimalkan interaksi antara guru dengan siswa, siswa dengan siswa, guru dengan siswa dan lingkungan, seakan interaksi banyak arah.

Dalam kegiatan pembelajaran, guru harus banyak memberi kesempatan kepada anak untuk melakukan praktik atau percobaan, menemukan sesuatu melalui pengamatan, penelitian dan sebagainya. Guru perlu mengenal kemampuan awal dan karakteristik setiap anak secara mendalam, baik dari segi kemampuan maupun ketidakmampuannya dalam menyerap materi pelajaran, kecepatan maupun kelambatannya dalam belajar, sehingga setiap kegiatan pembelajaran masing-masing anak mendapat perhatian dan perlakuan yang sesuai.

Prinsip menemukan, guru mengembangkan strategi pembelajaran yang mampu memancing anak terlibat secara aktif baik fisik maupun mental, sosial dan emosional. Prinsip pemecahan masalah Guru hendaknya sering mengajukan berbagai persoalan/problem yang ada di lingkungan sekitar dan anak dilatih untuk merumuskan, mencari data, menganalisis, dan memecahkannya sesuai dengan kemampuannya.

Peraturan Menteri Pendidikan Nasional Nomor 70 Tahun 2009 pasal 2 ayat 1 dan 2 menjelaskan pendidikan inklusi bertujuan untuk memberi kesempatan seluas-luasnya kepada semua peserta didik yang memiliki kelainan fisik, emosional, mental dan sosial, atau memiliki potensi kecerdasan dan atau bakat istimewa untuk memperoleh pendidikan yang bermutu sesuai dengan kebutuhan dan kemampuannya serta betujuan untuk mewujudkan penyelenggaraan pendidikan yang menghargai keanekaragaman dan tidak diskriminatif bagi semua peserta didik.

Buku Pedoman Umum Penyelenggaraan Pendidikan Inklusi Direktorat PSLB (Direktorat Pembinaan SLB, 2007) diuraikan bahwa tujuan penyelenggaraan pendidikan inklusi di Indonesia adalah pertama untuk memberikan kesempatan yang seluas-luasnya kepada semua anak mendapatkan pendidikan yang layak sesuai dengan kebutuhannya, termasuk anak-anak berkebutuhan khusus. Kedua membantu mempercepat program wajib belajar pendidikan dasar. Ketiga membantu meningkatkan mutu pendidikan dasar dan menengah dengan menekanangka tinggal kelas dan putus sekolah. Keempat menciptakan sistem pendidikan yang menghargai keanekaragaman, tidak diskriminatif, serta ramah terhadap pembelajaran. Dan kelima memenuhi ama-nat konstitusi.

Kebijakan dan peraturan perundangundangan secara nasional yang mendukung penyelenggaran pendidikan inklusif saat ini merujuk pada UUD 1945 alenia ke 4 pasal 31 ayat 1, UU Nomor 4 tahun 1997 tentang penyandang cacat dalam pasal 6 ayat 1, UU Nomor 23 Tahun 2002 tentang perlindungan anak dalam pasal 9 ayat 2, pasal 51 dan pasal 52, UU Nomor 20 tahun 2003 pasal 15, serta Permendiknas Nomor 70 tahun 2009 tentang pendidikan inklusif bagi peserta didik yang memiliki kelainan dan kecerdasan bakat/istimewa dalam dalam pasal 3 ayat 1 , pasal 5 ayat 2 , pasal 6 ayat 1,2 , dan 3 .

\section{Landasan Pedagogis}

Manusia dapat dididik sekaligus dapat mendidik serta saling mendidik sesamanya. Seorang manusia akan menjadi manusia yang sebenarnya hanya melalui pendidikan yang dilakukan oleh manusia lainnya. Pendidikan hanya mungkin terjadi apabila manusia itu berhubungan dengan manusia lainnya yang menyelenggarakan pendidikan.

\section{Landasan Empiris}

Penelitian tentang inklusif telah banyak dilakukan di negara-negara Barat sejak 1980-an, namun penelitian yang berskala besar dipelopori oleh The National Academy of Sciences (Amerika Serikat). Beberapa peneliti kemudian menyimpulkan bahwa pendidikan inklusif berdampak positif, baik terhadap perkembangan akademik maupun sosial anak berkelainan dan teman sebayanya.

Dilema yang perlu ditangani dengan kebijakan khusus (Sunaryo, 2009, pp. 9-10) yaitu: Sistem penerimaan siswa baru, khususnya ditingkat penjenjangan pendidikan menengah dan atas. Kesulitan jika mendasarkan pada ijazah akhirnya ditetapkan melalui umur. Dijadikannya pencapaian hasil ujian nasional sebagai kriteria sekolah bermutu, bukan diukur dari kemampuannya dalam mengoptimalkan kemampuan siswa secara komprehensif sesuai dengan keragaman. 
Penggunaan label rumah inklusif belum ada payung hukumnya, yang ada baru sekolah inklusif yaitu Peraturan Pemerintah Nomor 19 Tahun 2005 tentang Standar Pendidikan Nasional (Presiden Republik Indonesia, 2005) pasal 41 ayat 1 tentang keharusan memiliki tenaga kependidiakn khusus bagi sekolah inklusif sebagai alasan melakukan penolakan masuknya anak berkelainan ke sekolah yang bersangkutan yang ditandai dengan munculnya gejala "ekslusivisme baru", yaitu menolak anak berkebutuhan khusus dengan alasan belum memiliki tenaga khusus atau sekolahnya bukan sekolah inklusi.

Kurikulum pendidikan umum yang ada sekarang ini belum mengakamodasi keberadaan anak-anak yang memiliki perbedaan kemampuan (difabel). Masih dipahaminya pendidikan inklusif secara dangkal, yaitu sematamata memasukkan anak disabled children ke sekolah regular, tanpa upaya mengakmodasi kebutuhan khususnya. Kondisi ini dapat menjadikan anak tetap tereklusi dari lingkungan karena anak merasa tersisih, terisolasi, ditolak, tidak nyaman, sedih, marah dan sebagainya. Padahal makna inklusif adalah ketika lingkungan kelas atau sekolah mampu memberikan rasa senang, menerima, ramah, bersahabat, peduli, mencintai, menghargai, serta hidup dan belajar dalam kebersamaan.

Munculnya label khusus yang sengaja diciptakan oleh pemerintah maupun masyarakat yang cenderung membentuk sikap ekslusivisme. Kondisi ini tentu dapat berdampak pada sekolah inklusi sebagai sekolah kelas dua karena menerima anak berkebutuhan khusus dengan sekolah special school. Masih terbatasnya perhatian dan keseriusan pemerintah dalam mempersiapkan pendidikan inklusif secara matang dan komprehensif, baik dari aspek sosialisasi, penyiapan sumber daya maupun uji coba metode pembelajaran, sehingga hanya terkesan program eksperimental.

Melaksanakan sosialisasi tentang anak berkebutuhan khusus kepada guru melalui seminar, workshop dan lain sebagainya, sehingga guru memiliki pengetahuan dan pemahaman tentang anak berkebutuhan khusus yang valid. Dengan berubahnya pola pikir guru tentang anak berkebutuhan khusus, maka perlakuan mereka terhadap anak berkebutuhan khusus dapat berubah dan anak berkebutuhan khusus bukan lagi kelompok marginal yang perlu penanganan serius.
Kebijakan pemerintah sebagai komitmen untuk mewujudkan penyelenggaraan pendidikan inklusif di Indonesia, dapat ditandai dengan lahirnya Undang-Undang sebagai berikut. UU Nomor 4 Tahun 1997 Pasal 5 tentang Pernyandang Anak Cacat,Undang-Undang Nomor 23 Tahun 2002 Pasal 48 dan 49 tentang Perlindungan anak, Undang-Undang Nomor 20 Tahun 2003 Pasal 5, Ayat 1 sampai dengan 4 Tentang Sistem Pendidikan Nasional, Permendiknas Nomor 70 Tahun 2009 tentang Pendidikan Inklusif, PP No. 17 tahun 2010 pasal 127 sampai dengan 142, tentang Pengelolaan dan Penyelenggaraan Pendidikan.

Bahkan tahun 2002 pemerintah secara resmi mulai melakukan proyek ujicoba di sembilan propinsi yang memiliki pusat sumber dan sejak saat itu lebih dari 1500 siswa berkelainan telah bersekolah di sekolah regular. Pada tahun 2005 meningkat menjadi 6.000 siswa atau $5,11 \%$ dari seluruh jumlah anak berkebutuhan khusus, sedangkan pada tahun 2007 meningkat menjadi $7,5 \%$ atau 15.181 siswa yang tersebar di 796 sekolah inklusif yang terdiri dari 17 TK, 648 SD, 75 SLTP, dan 56 SLTA (Sunardi, 2009, p. 6).

Hal ini berarti pemerintah telah berupaya untuk mengimplementasikan kebijakan yang telah dibuat. Dari data yang diperoleh, tampaknya implementasi yang telah dilakukan menunjukan kuantitas yang progresif, namun pertanyaannya, apakah benar implementasi tersebut telah berhasil? Seperti dikatakan Pressman dan Wildavsky, "proses untuk melaksanakan kebijakan perlu mendapatkan perhatian yang seksama". Oleh sebab itu, keliru jika kita menganggap bahwa proses tersebut dengan sendirinya akan berlangsung mulus (Wahab, 2011, p. 135). Sedangkan Hogwood \& Gunn mengatakan bahwa kebijakan public itu sebenarnya mengandung resiko untuk gagal (Wahab, 2011, pp. 128-129).

Kegagalan dalam implementasi kebijakan dapat dilihat dari dua kategori besar, yaitu non-implemetation dan unsuccessfull implementation. Dalam kontek pendapat Hogwood \& Gunn, apa yang telah dilakukan pemerintah untuk mengimplementasikan kebijakannya tidak termasuk dalam dua kategori ini, namun juga tidak serta merta dianggap sebagai keberhasilan yang mutlak.

Pertanyaannya makna tersebut di atas telah terwujud menjadi sebuah kenyataan dalam implementasi kebijakan? Tentunya hal ini 
masih dapat disanggah dengan perkataan mana mungkin kebijakan itu mampu menghasilkan perubahan seketika. Apapun sanggahannya evaluasi tetap harus diarahkan pada pemahaman makna dari pendidikan inklusif itu sendiri.

Berikut dari sisi konten kebijakan yang terdapat dalam Undang-Undanga No 20 tahun 2003 tentang Sistem Pendidikan Nasional (Presiden Republik Indonesia, 2003), yang menyebutkan tujuan pendidikan nasional adalah berkembangnya potensi peserta didik agar menjadi manusia yang beriman dan bertaqwa kepada Tuhan Yang Maha Esa, berakhlak mulia, sehat, berilmu, cakap, kreatif, mandiri, dan menjadi warga Negara yang demokratis dan bertanggung jawab. Melalui pendidikan peserta didik berkelainan dibentuk menjadi warga negara yang demokratis dan bertanggung jawab, yakni individu yang mampu menghargai perbedaan, berpartisipasi dalam masyarakat. Tentunya ini masih menjadi pekerjaan besar untuk mengimplementasikan kebijakan tersebut.

Belum lagi pada kenyataan yang riil, yang terjadi di lapangan tentang pendidikan inklusif saat ini. Walaupun sudah terbit kebijakan yang secara yuridis mempunyai kekuatan hukum, namun dalam implentasinya masih banyak persoalan-persoalan yang terjadi, misalnya: Isu pemahaman pendidikan inklusif yang masih disamakan dengan integrasi, sehingga siswa harus menyesuaikan dengan sistem di sekolah. Isu kebijakan sekolah yang tidak mau menerima siswa berkebutuhan khusus dengan dalih tidak memiliki tenaga pendidik, fasilitas dan sebagainya. Isu tentang proses pembelajaran, misalnya guru masih belum bisa menerjemahkan kurikulum yang fleksibel, menentukan tujuan sampai pada evaluasi. Isu kondisi guru, belum adanya guru yang memiliki kualitas memadai sebagai guru pendidikan inklusif. Isu tentang lingkungan, dan sebagainya.

Dari berbagai dilema yang terjadi pada pendidikan inklusif di Indonesia, setidaknya harus segera diantisipasi dengan kebijakan-kebijakan khusus agar tidak menghalangi pelaksanaan implementasi kebijakan tentang pendidikan inklusif. Menurut Sunardi ada beberapa dilema yang perlu ditangani dengan kebijakan khusus (Sunardi, 2009, p. 20), yakni sistem penerimaan siswa baru, khususnya di tingkat pendidikan menengah dan atas yang menggunakan nilai ujian nasional sebagai kriteria penerimaan. Siswa hanya dapat diterima kalau hasil ujian nasionalnya memenuhi standar minimal yang telah ditetapkan oleh setiap sekolah. Dijadikannya pencapaian hasil ujian nasional sebagai kriteria sekolah bermutu, bukan diukur dari kemampuannya dalam mengoptimalkan kemampuan siswa secara komprehensif sesuai dengan keragaman. Penggunaan label sekolah inklusif dan adanya PP Nomor 19 tahun 2005 tentang Standar Nasional Pendidikan, pasal 41 ayat 1 tentang keharusan untuk memiliki tenaga kependidikan khusus bagi sekolah inklusif sebagai alasan melakukan penolakan masuknya anak berkelainan ke sekolah yang bersangkutan, yang ditandai dengan munculnya gejala esklusivisme baru, yaitu menolak anak berkebutuhan khusus dengan alasan belum memiliki tenaga khusus atau sekolahnya bukan sekolah inklusif. Kurikulum pendidikan umum yang ada sekarang ini belum mengakomodasi keberadaan anak-anak yang memiliki perbedaan kemampuan (difabel).

Masyarakat Kembaran Kabupaten masih memahami pendidikan inklusif secara dangkal, yaitu semata-mata memasukkan anak disabled children ke sekolah reguler, tanpa upaya untuk mengakomodasi kebutuhan khususnya. Kondisi ini dapat menjadikan anak tetap tereklusi dari lingkungan karena anak merasa tersisih, terisolasi, ditolak, tidak nyaman, sedih, marah, dan sebagainya. Pada hal makna inklusif adalah ketika lingkungan kelas atau sekolah mampu memberikan rasa senang, menerima, ramah, bersahabat, peduli, mencintai, menghargai, serta hidup dan belajar dalam kebersamaan.

Munculnya label khusus yang sengaja diciptakan oleh pemerintah maupun masyarakat yang cenderung membentuk sikap eksklusivisme, seperti Sekolah Unggulan, Sekolah Berstandar Internasional (SBI), Sekolah Rintisan Berstandar Internasional (RSBI), Sekolah Favorit, Sekolah Percontohan, Kelas Akselerasi, serta sekolah-sekolah yang berbasis agama. Kondisi ini tentu dapat berdampak kepada sekolah inklusif sebagai sekolah kelas dua (second class), karena menerima anak berkebutuhan khusus (ABK) sama dengan special school (sekolah khusus).

Terbatasnya perhatian dan keseriusan pemerintah dalam mempersiapkan pendidikan inklusif secara matang dan komprehensif, baik dari aspek sosialisasi, penyiapan sumber daya, maupun uji coba metode pembelajaran, sehingga hanya terkesan program eksperimental. 
Pendidikan inklusi yang diterapkan di Rumah inklusi desa Kembaran adalah pembebasan dengan sedapat mungkin menjamin hak setiap warga sekolah mendapatkan pendidikan, menghilangkan diskriminasi terhadap anak berkebutuhan khusus dan membantu meningkatkan mutu pendidikan. Hal ini yang dapat dirasakan langsung oleh anak, guru, orang tua dan masyarakat di Desa Kembaran Kecamatan Kebumen.

Di Rumah Inklusi Desa Kembaran Kecamatan dan Kabupaten Kebumen anak dalam mengikuti kegiatan belajar dalam seting inklusif antara lain pertama mengembangkan kepercayaan pada diri anak, merasa bangga pada diri sendiri atas prestasi yang diperolehnya. Kedua anak didorong untuk belajar secara mandiri, dengan mencoba memahami dan menerapkan pelajaran yang diperoleh di Rumah Inklusif ke dalam kehidupan sehari-hari di lingkungannya. Ketiga anak mampu berinteraksi secara aktif bersama teman-temannya, bersama guru-guru yang berada di lingkungan Rumah Inklusif dan masyarakat. Keempat anak dapat belajar untuk menerima adanya perbedaan, dan mampu beradaptasi dalam mengatasi perbedaan tersebut sehingga secara keseluruhan anak menjadi kreatif dalam pembelajaran.

Dalam pelaksanaan pendidikan di $\mathrm{Ru}-$ mah Inklusif guru dituntut untuk serta memperoleh keuntungan dari: pertama guru memperoleh kesempatan belajar dari cara mengajar dalam seting inklusif. Kedua terampil dalam melakukan pembelajaran kepada peserta didik yang memiliki latar belakang beragam. Ketiga mampu mengatasi berbagai tantangan dalam memberikan layanan kepada semua anak. $\mathrm{Ke}$ empat bersikap positif terhadap orang tua, masyarakat dan anak dalam situasi yang beragam. Kelima, mempunyai peluang untuk menggali dan mengembangkan serta mengaplikasikan berbagai gagasan baru melalui komunikasi dengan anak di lingkungan sekolah maupun di lingkungan masyarakat secara pro aktif, kreatif dan kritis.

Pada pendidikan di Rumah Inklusif ini, guru memperoleh kepuasan kerja dan pencapaian prestasi lebih tinggi ketika semua peserta didik mencapai keberhasilan. Dalam sekolah inklusif akan tercipta nuansa yang ramah terhadap pembelajaran dan terbuka kesempatan bagi para relawan untuk membantu pelaksanaan pembelajaran di kelas bekerjasama dengan guru-guru.
Respon orang tua dalam pembelajaran yang dilaksanakan di Rumah Inklusif antara lain adalah pertama para orang tua dapat belajar lebih banyak tentang bagaimana caracara mendidik anaknya, cara membimbing anaknya lebih baik di rumah dengan menggunakan teknik yang digunakan guru di sekolah. Kedua, secara pribadi terlibat dan akan merasakan keberadaannya menjadi lebih penting dalam membantu anak untuk belajar. Ketiga, orang tua akan merasa dihargai, mereka merasa dirinya sebagai mitra sejajar dalam memberikan kesempatan belajar yang berkualitas kepada anaknya. Dengan pelaksanaan pendidikan inklusif orang tua akan dapat berinteraksi dengan orang lain, serta memahami dan membantu memecahkan masalah yang terjadi di lingkungan masyarakat. Keempat orang tua mengetahui bahwa anaknya dan semua anak yang ada di sekolah, menerima pendidikan yang berkualitas sesuai dengan kemampuan masing-masin individu anak.

Masyarakat Desa Kembaran dalam pelaksanaan pendidikan inklusif di Rumah Inklusif mendapatkan pertama masyarakat akan merasakan suatu kebanggaan karena lebih banyak anak mengikuti pendidikan di lembaga yang ada dilingkungannya. Masyarakat dapat melihat bahwa masalah yang menyebabkan penyimpangan sosial yang menjadi penyakit masyarakat akan dikurangi dengan adanya layanan pendidikan inklusif untuk semua. Kedua semua anak yang ada di masyarakat akan terangkat dan menjadi sumber daya yang potensial. Lebih penting adalah masyarakat akan lebih terlibat di sekolah dalam rangka menciptakan hubungan yang lebih baik antara sekolah dan masyarakat.

\section{SIMPULAN}

Temuan equality pedagogy yang dilaksanakan di Rumah Inklusif adalah terjadinya praktik pendidikan pembebasan yang menempatkan anak luar biasa atau anak dengan kebutuhan khusus belajar bersama dengan anak normal dalam satu kelas di rumah joglo yang dekat dengan tempat tinggalnya. Yang dimaksud pembebasan adalah siswa diberikan keleluasaan untuk menentukan sendiri menu pendidikannya.

Tantangan equality pedagogy di rumah inklusif Kembaran Kebumen adalah minimnya pemahaman masyarakat umum terha- 
dap kondisi anak-anak difabel. Dalam proses pendidikannya rumah inklusif terbatas dari sisi sarana-prasarana dan kurangnya tenaga relawan pendamping anak-anak difabel. Hal ini terbukti dengan banyaknya fasilitas publik terutama di Kebumen yang tidak ramah difabel.

Lahirnya rumah inklusif di Kebumen adalah sebuah bentuk perlawanan terhadap minimnya perhatian pemerintah dalam menangani anak-anak berkebutuhan khusus di Kebumen. Pemerintah belum melakukan apa-apa, justeru mengeksklusifkan anak-anak difabel dalam sekolah-sekolah Luar Biasa. Hal ini membuat para siswa dan orang tua merasa minder. Dari pelaksanaan pendidikan di Rumah Inklusif yang dapat mengambil keuntungan adalah siswa, guru, orang tua, dan masyarakat dalam memahami dan melibatkian diri dalam persoalan difabilitas.

\section{DAFTAR PUSTAKA}

Direktorat Pembinaan SLB. (2007). Pedoman umum penyelenggaraan pendidikan inklusif. Jakarta: Depdiknas.

Geniofam. (2010). Mengasuh dan mensukseskan anak berkebutuhan khusus. Yogyakarta: Gerai Ilmu.

Ilahi, M. T. (2013). Pendidikan inklusif: konsep dan aplikasi. Jogjakarta: ArRuzz Media.

Indianto, R. (2013). Materi implementasi pendidikan inklusi. Surabaya: Universitas Sebelas Maret.

Iswari, M. (2008). Kecakapan hidup bagi anak berkebutuhan khusus. Padang: UNP Press.

Khalsa, S. (2004). Inclusive classroom a practical guide for education. Laverett: Permission Publisher.

Menteri Pendidikan Nasional Republik Indonesia. Peraturan Menteri Pendidikan Nasional RI Nomor 70 Tahun 2009 tentang Pendidikan Inklusif bagi Peserta Didik yang Memiliki Kelainan dan Memiliki Potensi Kecerdasan dan/atau
Bakat Istimewa (2009).

Moleong, L. J. (2001). Metode penelitian kualitatif. Bandung: PT Remaja Persada Rosda Karya.

Mudjito, Harizal, \& Elfindri. (2012). Pendidikan inklusif. (Wardi, Ed.). Jakarta: Baduose Media.

Nasution, S. (1988). Metode penelitian naturalistik kualitatif. (Tarsito, Trans.). Bandung.

Presiden Republik Indonesia. Undang-Undang Republik Indonesia nomor 20 tahun 2003 tentang Sistem Pendidikan Nasional (2003). Indonesia.

Presiden Republik Indonesia. Peraturan Pemerintah Republik Indonesia Nomor 19 Tahun 2005 tentang Standar Nasional Pendidikan (2005).

Sapon-Shevin, M. (2007). Widening the circle: the power of inclusive classrooms. Boston: Bacon Press.

Smith, D. (2012). Sekolah inklusif konsep dan penerapan pembelajaran. Bandung: Nuansa.

Sunardi. (2009). Issues and problems on implementation of inclusive education for disable children in Indonesia. Tsukuba: Criced-University of Tsukuba.

Sunaryo. (2009). Manajemen pendidikan inklusi. Bandung: FIP UPI.

Tarmansyah. (2009). Perspektif pendidikan inklusif. Padang: UNP Press.

Wahab, S. A. (2011). Pengantar analisis kebijakan publiK. Malang: UMM Press. 